Saudi Journal of Business and Management Studies Abbreviated Key Title: Saudi J Bus Manag Stud ISSN 2415-6663 (Print) |ISSN 2415-6671 (Online) Scholars Middle East Publishers, Dubai, United Arab Emirates Journal homepage: https://saudijournals.com

Original Research Article

\title{
Leadership and Organizational Culture Effects on Employee Performance and Variables Customer Satisfaction as Intervening (Case Study at PT. Sukaputra Graha Cemerlang Sentul City)
}

Janni Tuahman Saragih ${ }^{1 *}$, Ahmad Badawi Saluy ${ }^{2}$

${ }^{1}$ Menteng Campus J1. Menteng Raya No. 29 Central Jakarta, Indonesia

${ }^{2}$ Head Lecturer, Meruya Campus Jl. Meruya Selatan No. 1 Kembangan West Jakarta 11650, Indonesia

DOI: $10.36348 /$ sjbms.2022.v07i01.002 $\quad$ | Received: 11.12.2021 | Accepted: 20.01.2022 | Published: 24.01.2022

*Corresponding author: Janni Tuahman Saragih

Menteng Campus Jl. Menteng Raya No. 29 Central Jakarta, Indonesia

\section{Abstract}

This study aims to determine and analyze the effects of leadership and organizational culture on employee performance and customer satisfaction variables as an intervening at PT. Sukaputra Graha Cemerlang Sentul City. Quantitative descriptive method with a causal relationship approach is the method used in this study. The population selected in this study were all employees of PT. Sukaputra Graha Cemerlang in Sentul City with a population of 217 people. Of all the population samples taken based on the Slovin formula are 141 samples. Data analysis using Structural Equation Model (SEM) with SmartPLS (Partial Least Square) 3.0. The results showed that leadership style had a positive and significant effect on customer satisfaction, organizational culture had a positive and significant influence on customer satisfaction, leadership style and organizational culture had a positive and significant influence on customer satisfaction, and customer satisfaction had a positive and significant effect on performance. employees of PT. Sukaputra Graha Cemerlang in Sentul City. Customer satisfaction can mediate the influence between leadership style and organizational culture with the performance of employees of PT. Sukaputra Graha Cemerlang in Sentul City.

Keywords: Leadership, organizational culture, employee performance, customer satisfaction.

Copyright (C) 2022 The Author(s): This is an open-access article distributed under the terms of the Creative Commons Attribution 4.0 International License (CC BY-NC 4.0) which permits unrestricted use, distribution, and reproduction in any medium for non-commercial use provided the original author and source are credited.

\section{INTRODUCTION}

Many important factors move the company in carrying out activities, but human resources remain the number one factor to achieve company goals. Human resources can be said as the company's main source of energy because without human resources all equipment from manual to automatic ones will not work optimally. Therefore, if human resources are managed properly, employee performance will increase and it will propagate to company performance so that company goals can be achieved. The company's organizational performance is a multi-dimensional thing that emphasizes the achievement of business growth and profitability (Rekarti, Doctoralina \& Saluy, 2020). High employee performance can affect the achievement of company goals.
This research was carried out at PT. Sukaputra Graha Cemerlang in Sentul City Bogor which is a show company PT. Sentul City Tbk assigned to manage the environment throughout the Sentul City area. The environmental management is expected to provide benefits for all residents there, especially Sentul City consumers. PT. Sukaputra Graha Cemerlang in managing the environment includes all forms of environmental and infrastructure maintenance including: roads such as public road arrangements and road cleanliness, water channels such as clean and dirty water pipelines, maintenance of retaining walls, regional safety (security), park conservation, places parking, transporting household waste around and other things. 
Janni Tuahman Saragih \& Ahmad Badawi Saluy., Saudi J Bus Manag Stud, Jan, 2022; 7(1): 11-21

Services performed by PT. Sukaputra Graha Cemerlang has not been maximized so that it does not satisfy its customers or business partners. There are still important policies taken by the company, not involving customers or local residents. As a result, the policy results have been criticized and even met with resistance from the emergence of various citizen committees to oppose company policies. This has resulted in a prolonged conflict
Based on a initial survey carried out by the author to 30 respondents about customer satisfaction, it shows that customer satisfaction is still unsatisfactory or not as expected by the customers of PT. Sukaputra Graha Cemerlang, which is presented in the following table:

Table 1: Customer Satisfaction Initial Survey

\begin{tabular}{|c|c|c|c|c|}
\hline \multirow[t]{2}{*}{ No } & \multirow[t]{2}{*}{ Items of Questions } & \multicolumn{2}{|c|}{ Answer } & \multirow{2}{*}{$\begin{array}{l}\text { Sum } \\
\text { of }\end{array}$} \\
\hline & & Yes & No & \\
\hline 1 & I am satisfied with the service performance provided by the company & $\begin{array}{l}17 \\
(57 \%)\end{array}$ & $\begin{array}{l}13 \\
(43 \%) \\
\end{array}$ & $\begin{array}{l}30 \\
(100 \%)\end{array}$ \\
\hline 2 & Complaints and suggestions from the customer are handled well by the $\mathrm{c}$ & $\begin{array}{l}16 \\
(53 \%) \\
\end{array}$ & $\begin{array}{l}14 \\
(47 \%) \\
\end{array}$ & $\begin{array}{l}30 \\
(100 \%)\end{array}$ \\
\hline 3 & I feel happy with the condition of the housing environment & $\begin{array}{l}17 \\
(57 \%)\end{array}$ & $\begin{array}{l}13 \\
(43 \%)\end{array}$ & $\begin{array}{l}30 \\
(100 \%)\end{array}$ \\
\hline 4 & I feel happy renting a building managed by a company & $\begin{array}{l}18 \\
(60 \%)\end{array}$ & $\begin{array}{l}12 \\
(40 \%)\end{array}$ & $\begin{array}{l}30 \\
(100 \%)\end{array}$ \\
\hline 5 & $\begin{array}{l}\text { I am satisfied with the company's environmental management and ca } \\
\text { recommend to others }\end{array}$ & $\begin{array}{l}19 \\
(63 \%)\end{array}$ & $\begin{array}{l}11 \\
(37 \%)\end{array}$ & $\begin{array}{l}30 \\
(100 \%)\end{array}$ \\
\hline
\end{tabular}

Source: Initial Survey, processed (2021)

It can be seen in the results of the survey described in table 1 above, it can be concluded that customer satisfaction is still less than optimal.

Customer satisfaction in this case can be effected by employee performance. Employee performance can be described as the skill of the employee to perform the given task. Employee performance is something that the company needs, because with the company's performance it can be seen how far their dexterity is in carrying out the tasks they receive (Sinambela, 2016: 480). While customer satisfaction is the pleasure and disappointment of individual feelings that arise after comparing their perceptions, impressions, and expectations of the performance or results of a product (Kotler, 2016: 36).

To enable the goals of a company to be achieved, it requires the efforts of all parties bound to the company or organization. If viewed carefully, there is a strong relationship between individual performance and institutional performance or company performance. In short, it can be said that high employee performance can make the company's performance high as well. If employees have professional employee skills, work for salaries and wages according to the agreement, have high expectations for the future, then the probability of their performance is also high.

High employee performance has high morale, can complete work according to targets, has high commitment so that employees can provide good service to their customers. High employee performance is indicated by the presence of employees who are quick to respond, serve without discrimination, on time, follow up on customer complaints quickly, and are friendly in attitude. This situation can ultimately satisfy customers or meet their expectations from the services obtained. It can be concluded that employee performance has an effect on customer satisfaction.

The discussion above has similarities with the findings of research carried out by Nursiti and Fedrick (2018), where the research describes employee performance as the key to success in providing services that satisfy consumers because company employees can interact directly with consumers. The research findings also conclude that employee performance has a significant effect on customer satisfaction.

Employee performance and customer satisfaction in this study can be effected by leadership style. Leadership style can be explained as the ability of an individual to effect others by motivating, and making others contribute more to the smoothness and success of the organization (Yukl, 2015: 4).

Leadership style is a method that leaders use in effecting their subordinates. In order for the leadership style to be effective, the leadership needs to be in accordance with the maturity level of the subordinates who are effected by the leader. A leadership style that is practiced correctly by leaders will make subordinates able to work more comfortably, comply with regulations, work according to targets, feel safe and have high enthusiasm at work. This situation can have an impact on increasing employee performance and also affect customer satisfaction. 
Janni Tuahman Saragih \& Ahmad Badawi Saluy., Saudi J Bus Manag Stud, Jan, 2022; 7(1): 11-21

This discussion has similarities with the findings of research carried out by Altun et al (2020), Fakhri et al., (2020), Yusuf-Habeeb \& Ibrahim (2017), Saluy, Prawira \& Buntaran (2019), Salah \& Majid (2016), Genç \& Karadirek (2018), Siwu et al., (2016), where their research findings explain that leadership style has a significant influence on employee performance and customer satisfaction. However, the discussion above is not in accordance with the findings of research carried out by Hakim \& Al-Hakim (2020), where the findings conclude that leadership style has no effect on employee performance.

In addition to leadership style, employee performance can also be effected by organizational culture factors. A system of understanding that is shared by every member of the organization or company so that it distinguishes them from other organizations is called organizational culture (Robbins \& Judge (2017: 256). While Kreitner \& Kinicki (2017: 62) explain that organizational culture is an identity organization or company based on shared values and beliefs.

Organizational culture has a function as a guide in solving every problem in the organization by shaping employee attitudes and guiding their behavior through the values of attitudes and norms that are followed. In addition, organizational culture can also be used to control the attitudes and behavior of each member of the organization to further innovate in achieving goals.

If implemented correctly by every member of the organization, the organizational culture can create a conducive environment, so that the work of employees can run smoothly, work morale is increased, a sense of comfort and security in working is guaranteed well, the work environment is kept clean and so on. This situation can ultimately improve employee performance.

This discussion has similarities with the findings of research carried out by Isa et al., (2016), Muizu and Sari (2019), Paschal \& Nizam (2016), Saluy, Prawira \& Buntaran (2019). Nuryanto, Sutawidjaya \& Saluy (2020), Siwu et al., (2016), Rahmaddian et al., (2021), where their findings explain that organizational culture has a significant effect on employee performance and customer satisfaction.

\section{LITERATURE REVIEW \\ Employee performance}

Sinambela (2016: 480) explains performance as an employee's expertise in carrying out certain tasks. With employee performance, the company can see how high the expertise of employees is in completing the tasks given. The achievement of an individual's work is referred to as employee performance. This achievement is seen based on evaluations and certain standards applied by the company where individuals are given roles or tasks during a certain period (Saluy \& Treshia, 2018).

The achievement of a company's goals can only occur due to the intervention of all individuals in the organization. Based on this, it can be said that the performance of each individual reflects the company's overall performance. That is, if the performance of each employee has increased, the company's performance will also increase. A performance improvement plan needs to be made if the employee's performance is not up to standard. Physical ability is not the only thing that is assessed when assessing the performance of an employee, but all employee performance activities. This includes various things such as crafts, work relations, discipline, work ability or other related things in line with the level of work and field (Siswanto and Hamid, 2017).

\section{Customer satisfaction}

Supranto (2013: 44) argues that customer satisfaction is a sign shown by customers in concluding all the results of services or products they see or feel. For example, when a customer sees a product and he smiles because of it, the customer gives a sign that he feels there is satisfaction in seeing the product.

Sumarwan (2015: 322) defines consumer satisfaction as the level of feeling that occurs when consumers compare their expectations of the performance or results they feel to the services or products they receive. In other words, satisfaction becomes a function of comparing expectations with perceived performance. Performance that is below expectations will result in disappointment, while performance that is in line with expectations will result in gain.

Satisfaction or dissatisfaction is born from disconfirmation of expectations, which means that customer satisfaction or dissatisfaction is formed from a comparison of expectations before and after purchasing a product or service. Customers put expectations when buying or using a product is how they consider whether or not the product or service functions (Sumarwan, 2015:322).

\section{Leadership Style}

Achieving or not achieving organizational goals can be determined by several factors, one of which is leadership style. Leadership style is a skill in effecting something such as an organization in order to achieve goals more effectively. Leadership style has a major role in understanding behavior and guiding a group because giving a direction for one goal is the task of the leader (Robbins and Judge, 2017: 24).

At its root, leadership style has meaning and understanding as a real embodiment of the leader's behavior related to his ability to lead. This real 
Janni Tuahman Saragih \& Ahmad Badawi Saluy., Saudi J Bus Manag Stud, Jan, 2022; 7(1): 11-21

embodiment will give birth to a certain form according to the ability of the leader. The definition of leadership style has similarities with the opinion conveyed by Yukl, (2015: 4) which defines leadership style as a leader's agility in motivating, effecting and directing other people or subordinates so that they are able to contribute to the effectiveness and success of organizational goals.

According to Siagian's opinion (2015:76); There are five recognized leadership styles, namely; 1) Authoritarian leadership style, 2) Paternalistic style, 3) Charismatic style, 4) Laisez Faire style and 5) Democratic leadership style.

\section{Organizational Culture}

Rivai dan Mulyadi (2015:374), explain that organization culture as a working scheme being basic guideline of attitue in directing employees action to acchieve the organization goal as well as to be base of decision making.

Meanwhile Robbins and Judge (2017:256) said that organizational culture is a "mutual meaning" that shared by members that differentiate an organization from other organizations". Kreitner and Kinicki (2017:62) organization culture is mutual values and confidence grounding company identity. Mangkunegara (2017:113) explained that organization culture as part of confident in values norm developing in an organization to be reference in all behaviors of members so that it can be outcomed of all problems of external and internal adaptation.

Based on aboved description this can be made conceptual framework in this figure:

Framework

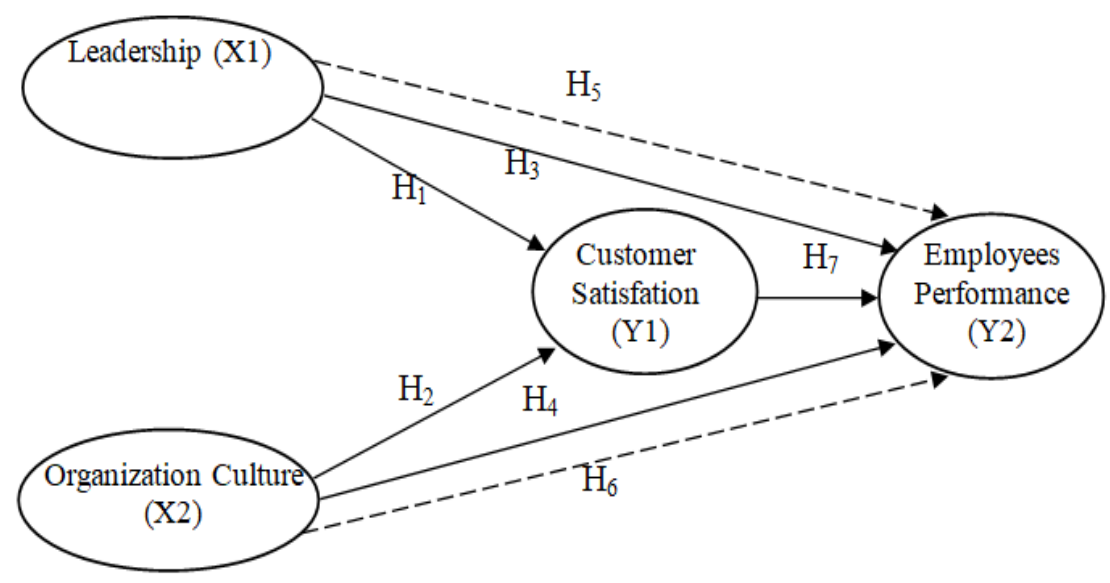

Figure 1: Framework

\section{Research Hypothesis}

H1 The leadership style is suspected to have an effect on customer satisfaction at PT. Sukaputra Graha Cemerlang.

$\mathrm{H} 2$ Organizational culture is suspected to have an effect on customer satisfaction at PT. Sukaputra Graha Cemerlang.

H3 Leadership style is suspected to have an effect on employee performance at PT. Sukaputra Graha Cemerlang.

H4 Organizational culture is suspected to have an effect on employee performance at PT. Sukaputra Graha Cemerlang.

H5 Leadership style is suspected to have an effect on employee performance at PT. Sukaputra Graha Cemerlang mediated by customer satisfaction.

H6 Organizational culture is suspected to have an effect on employee performance at PT. Sukaputra Graha Cemerlang mediated by customer satisfaction.
H7 Customer satisfaction is suspected to have an effect on employee performance at PT. Sukaputra Graha Cemerlang.

\section{RESEARCH METHOD}

Quantitative descriptive method with a causal approach is the method used in this study. All employees of PT. Sukaputra Graha Cemerlang in Sentul City The population was applied as the population in this study with a sample of 141 respondents. The hypothesis was tested using the Structural Equation Model (SEM) and SmartPLS (Partial Least Square) 3.0 approaches. as analysis software.

\section{RESULT AND DISCUSSION \\ Evaluatio of Outer Model \\ Convergent Validity}

Pengujian convergent validity dlilakukan dengan menggunakan hasil outer loading/loading factor. Indikator yang memenuhi convergent validity atau dinyatakan ada pada kategori baik harus memiliki nilai outer loading $>0,7$. 


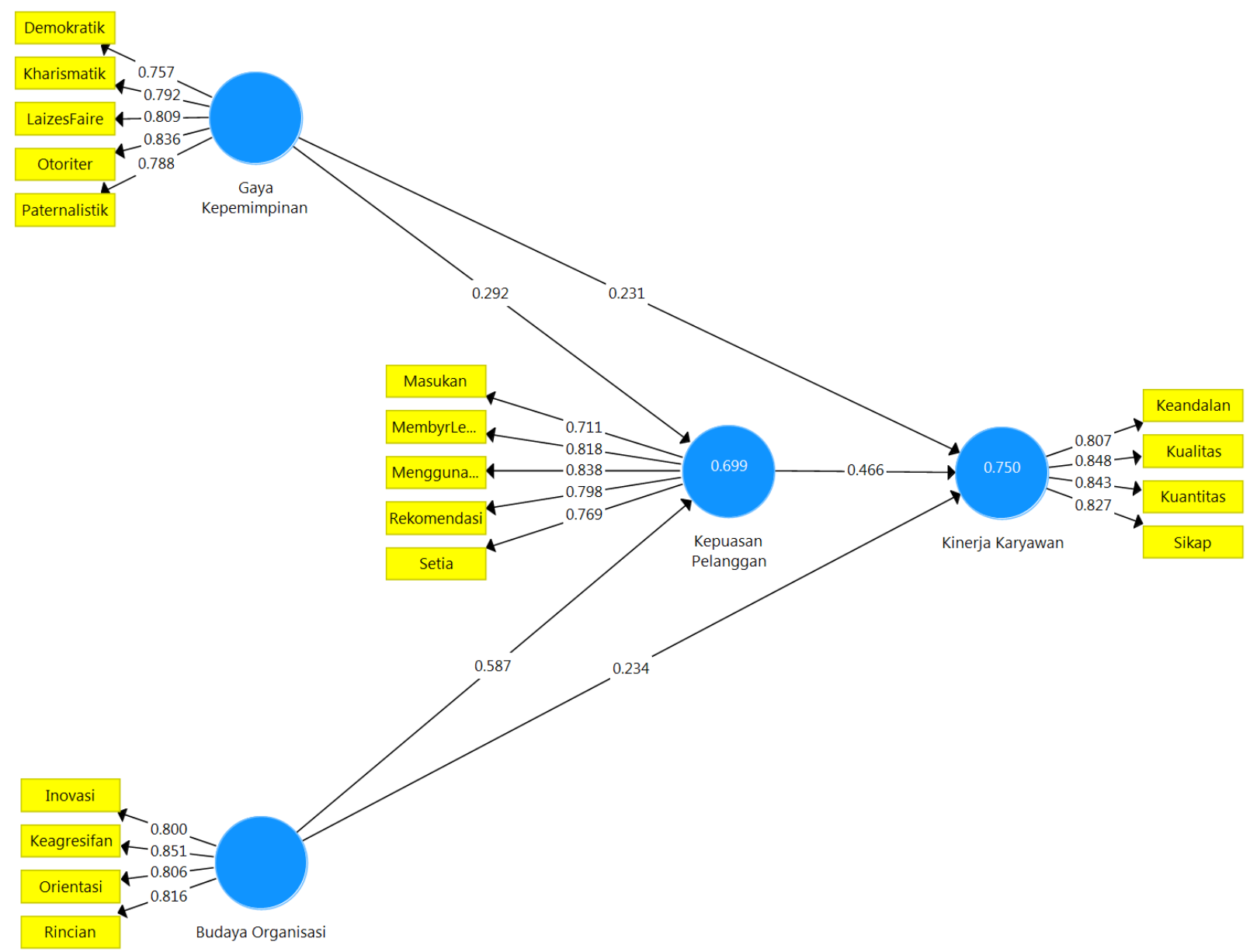

Figure 2: Outer Model

Table 2: Outer Loading

\begin{tabular}{|l|l|l|l|}
\hline Variables & Indicators & Outer Loading & Reliability \\
\hline \multirow{4}{*}{ Leadership style (X1) } & Authoritarian style & 0.836 & Reliable \\
\cline { 2 - 4 } & Paternalistic style & 0.788 & Reliable \\
\cline { 2 - 4 } & Charismatic style & 0.792 & Reliable \\
\cline { 2 - 4 } & Laisez faire style & 0.809 & Reliable \\
\cline { 2 - 4 } & Democratic style & 0.757 & Reliable \\
\hline Organizational culture (X2) & Innovation and risk-taking & 0.800 & Reliable \\
\cline { 2 - 4 } & Attention to details & 0.816 & Reliable \\
\cline { 2 - 4 } & Result orientation & 0.806 & Reliable \\
\cline { 2 - 4 } & Aggressiveness & 0.851 & Reliable \\
\hline Customer satisfaction (Z) & Stay Loyal & 0.769 & Reliable \\
\cline { 2 - 4 } & Using services & 0.838 & Reliable \\
\cline { 2 - 4 } & Recommend & 0.798 & Reliable \\
\cline { 2 - 4 } & Pay more & 0.818 & Reliable \\
\cline { 2 - 4 } & Give feedback & 0.711 & Reliable \\
\hline Employee performance (Y) & Quality of work & 0.848 & Reliable \\
\cline { 2 - 4 } & Quantity of work & 0.843 & Reliable \\
\cline { 2 - 4 } & Reliability & 0.807 & Reliable \\
\cline { 2 - 4 } & Attitude & 0.827 & Reliable \\
\hline
\end{tabular}

Output PLS, 2021

It can be seen in Table 2 that each indicator in each research variable has an outer loading value above 0.6. These results prove that the outer loading value meets the convergent validity requirements, where the outer loading value is between $0.5-0.6$, as stated by Chin in Imam Ghozali (2014:39). It can be concluded 
Janni Tuahman Saragih \& Ahmad Badawi Saluy., Saudi J Bus Manag Stud, Jan, 2022; 7(1): 11-21

that each indicator is declared valid or feasible to be used as research and for further analysis.

Discriminant Validity

Discriminant validity testing is based on the results of average variant extracted (AVE), which must be $>0.5$ for each variable as a good model requirement. The results of the discriminant validity test can be seen below:

Table 3: Average Variant Extracted

\begin{tabular}{|l|l|l|}
\hline Variabel & AVE & Validity \\
\hline Leadership style & 0.635 & Valid \\
\hline Organizational culture & 0.670 & Valid \\
\hline Customer satisfaction & 0.621 & Valid \\
\hline Employee performance & 0.691 & Valid \\
\hline \multicolumn{2}{|c|}{ Output PLS, 2021}
\end{tabular}

Table 3 shows the AVE results for the variables of leadership style, organizational culture, customer satisfaction and employee performance worth $>0.5$. Thus, it can be concluded that each variable has good discriminant validity.

\section{Composite Reliability}

The reliability value of each indicator in a variable is tested using Composite Reliability. In fulfilling the test requirements, each variable must have a composite reliability of $>0.7$. The following table displays the composite reliability value of each variable:

Table 4: Composite Reliablity)

\begin{tabular}{|l|l|l|}
\hline Variabel & Composite Reliabilty & Reliability \\
\hline Leadership style & 0.897 & Reliable \\
\hline Organizational culture & 0.890 & Reliable \\
\hline Customer satisfaction & 0.891 & Reliable \\
\hline Employee performance & 0.899 & Reliable \\
\hline
\end{tabular}

Output PLS, 2021,

It can be seen from Table 4 that the composite reliability results obtained for each research variable are worth 0.7. This means that all variables are Reliable with a high level because they have fulfilled composite reliability.

\section{Cronbach Alpha}

Cronbach alpha was used to reinforce previous reliability tests. Variables that meet the requirements of cronbach alpha must have a cronbach alpha value > 0.75 The table below is a breakdown of the cronbach alpha values for each variable:

Table 5: Cronbach Alpha

\begin{tabular}{|l|l|l|}
\hline Variables & Cronbach Alpha & Reliability \\
\hline Leadership style & 0.856 & Reliable \\
\hline Organizational culture & 0.836 & Reliable \\
\hline Customer satisfaction & 0.846 & Reliable \\
\hline Employee performance & 0.851 & Reliable \\
\hline
\end{tabular}

Output PLS, 2021

Table 5 shows that the Cronbach alpha value of each research variable is $\geq 0.7$. In other words, each variable in the study has met the requirements of the Cronbach alpha value, meaning that all variables have a high level of reliability.

\section{Evaluation of Inner Model}

The inner model (structural model) tested includes the output r-square, parameter coefficients and t-statistics used to test the hypothesis. Acceptance or rejection of a hypothesis can be seen in the significance value between constructs, t-statistics, and p-values. The value of the proof can be seen in the bootstrapping results. T-statistic $>1.96$ with a significance level of $p$ value $0.05(5 \%)$ and a positive beta coefficient is the rule of thumb used in this study. The results of the boot strapping research model are described through the inner model below: 


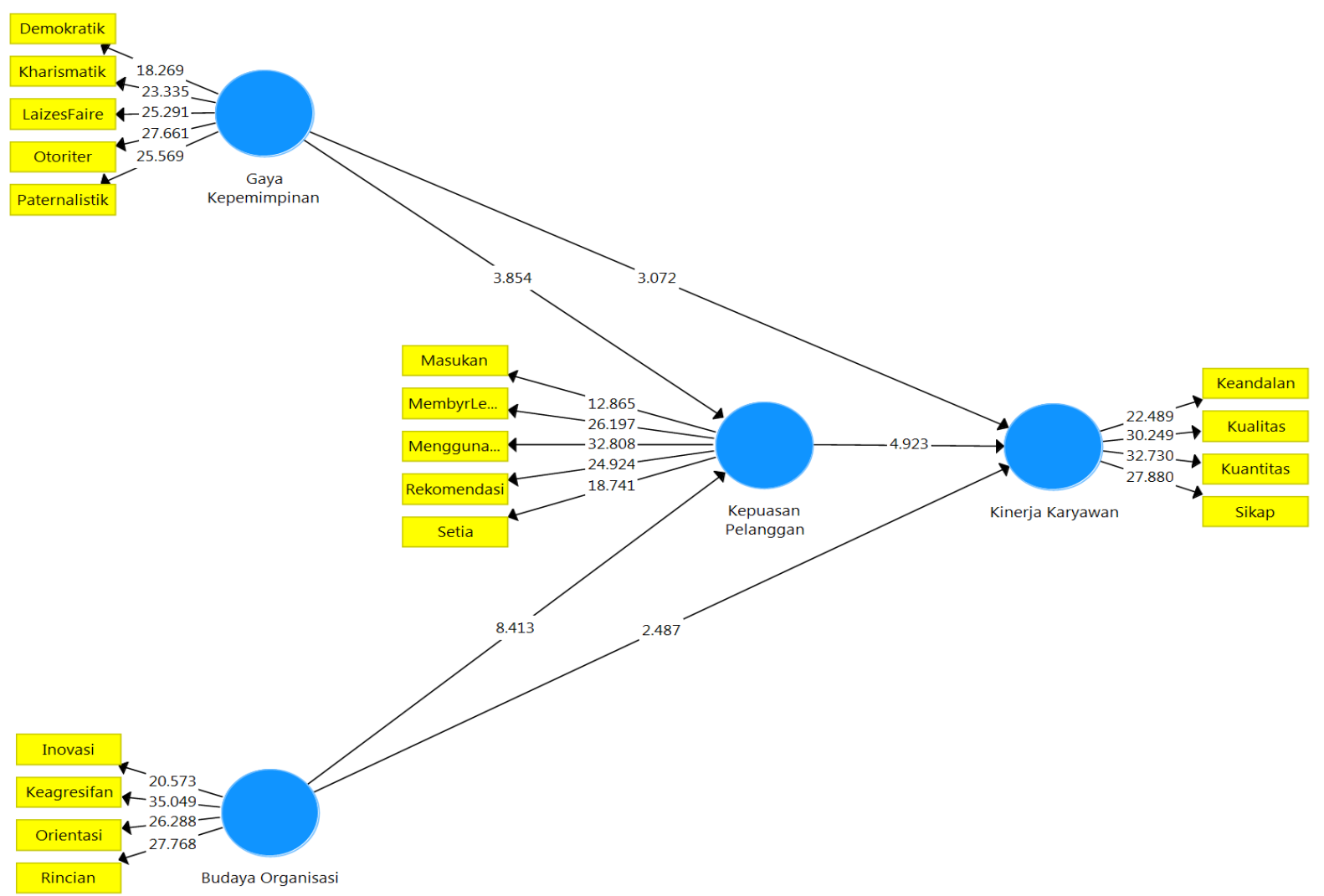

Figure 3: Inner Model

\section{Path Coefficient Test}

Path coefficient testing aims to tell how much influence or effect the independent variable has on the dependent variable. Furthermore, the determination coefficient (R-Square) is used to find out how much the endogenous variable is effected by other variables. Chin in Ghozali (2014:42) explains that for endogenous latent variables that are in the good category, the result of R2 must be 0.67 and above. While the results are worth $0.33-0.67$ will be included in the medium category, and if the results are worth $0.19-0.33$ will be included in the weak category.

It can be seen in Figure 2. The outer model schema explains that the path coefficient results on the most dominant path coefficient are found in the organizational culture variable on customer satisfaction which is worth 0.583 . Then the second path coefficient is found in the customer satisfaction variable on employee performance which is worth 0.831 . While the smallest value is found in the leadership style variable on customer satisfaction which is worth 0.297.

It can be seen in Figure 3. The schematic of the inner model shows the largest t-statistic value shown in organizational culture to customer satisfaction which is worth 8.413. Furthermore, the second largest effect is seen in the effect of customer satisfaction on employee performance which is worth 4.923 . While the smallest effect is found in the organizational culture variable on employee performance which is worth 2,487.
Based on the discussion of these results, it can be said that in this research model the independent variable on customer satisfaction has a path coefficient value with positive results. This reflects that if the value of the path coefficient on one of the independent variables on the customer satisfaction variable is getting bigger, it will make the effect between the independent variables stronger on the customer satisfaction variable. Furthermore, the independent variable on employee performance in this model has a path coefficient value with positive results. This reflects that if the path coefficient value in one of the independent variables on the employee performance variable is greater, the stronger the effect between the independent variables on the employee performance variable will be.

\section{Goodness of Fit Test}

Table 6: R-Square Values

\begin{tabular}{|l|l|}
\hline Variabel & Nilai R Square \\
\hline Customer satisfaction & 0,699 \\
\hline Employee performance & 0,750 \\
\hline \multicolumn{2}{|r|}{ Output PLS, 2021}
\end{tabular}

Table 6 shows that the R-Square value on the customer satisfaction variable is 0.699. This value explains that customer satisfaction can be effected by variables of leadership style and organizational culture by $69.9 \%$ while the remaining $30.1 \%$ can be effected by other variables not examined. Furthermore, the employee performance variable has an R-Square value 
Janni Tuahman Saragih \& Ahmad Badawi Saluy., Saudi J Bus Manag Stud, Jan, 2022; 7(1): 11-21

of 0.750. This value explains that employee performance can be effected by customer satisfaction variables by $75 \%$ while the remaining $25 \%$ can be effected by other variables not examined.

\section{Hypothesis testing}

Hypothesis testing is carried out to see the direct effect between leadership style and organizational culture with customer satisfaction and employee performance, then customer satisfaction on self performance by looking at the path coefficient described in Table o below:

Table 7: Direct and Indirect Effect

\begin{tabular}{|l|l|l|l|l|l|}
\hline $\begin{array}{l}\text { Hypo } \\
\text { thesis }\end{array}$ & Effects & $\begin{array}{l}\text { Original } \\
\text { Sample }\end{array}$ & $\begin{array}{l}\text { T- } \\
\text { Statistik }\end{array}$ & $\begin{array}{l}\text { P- } \\
\text { Values }\end{array}$ & Results \\
\hline H1 & Leadership Style => Customer Satisfaction & 0,292 & 3,854 & 0,000 & Accepted \\
\hline H2 & Organizational Culture => Customer Satisfaction & 0,587 & 8,413 & 0,000 & Accepted \\
\hline H3 & Leadership Style => Employee Performance & 0,231 & 3,072 & 0,002 & Accepted \\
\hline H4 & Organizational Culture on => Employee Performance & 0,234 & 2,487 & 0,0013 & Accepted \\
\hline H7 & Customer Satisfaction => Employee Performance & 0,466 & 4,923 & 0,000 & Accepted \\
\hline H5 & $\begin{array}{l}\text { Leadership Style => Employee Performance mediated } \\
\text { by Customer Satisfaction }\end{array}$ & 0,136 & 2,819 & 0,005 & Accepted \\
\hline H6 & $\begin{array}{l}\text { Organizational Culture => Employee Performance } \\
\text { mediated by Customer Satisfaction }\end{array}$ & 0,273 & 4,562 & 0,000 & Accepted \\
\hline
\end{tabular}

Output PLS, 2021

\section{DISCUSSION OF RESEARCH RESULTS The Effect of Leadership Style on Customer Satisfaction}

The results of the research analysis obtained a t-value of $3.849>1.96$, meaning that leadership style has a significant and positive effect on customer satisfaction. The path coefficient with a value of 0.297 means that leadership style contributes to customer satisfaction with a value of $29.7 \%$ and the remaining $70.3 \%$ is another factor not investigated.

Leadership style is a technique used by leaders in guiding their subordinates. The leadership style becomes more effective when the leader exerts leadership effect according to the maturity level of the subordinate group. The leadership style that is practiced well by the leaders makes subordinates able to work more comfortably, comply with regulations, work according to targets, feel safe and have high enthusiasm at work. This situation can have an impact on employees in working to serve customers increasing so that it can affect customer satisfaction.

\section{The effects of Organizational Culture on Customer Satisfaction}

The results of the research analysis obtained a t-value of $8.360>1.96$, which means that organizational culture has a significant and positive effect on customer satisfaction. The path coefficient, which is 0.583 , means that organizational culture contributes to customer satisfaction by $58.3 \%$ and the remaining $41.7 \%$ is another factor not investigated.

Organizational culture serves as a reference for controlling and realizing employee attitudes and character through values and norms in solving all problems within the organization. With organizational culture, a review of the attitudes and character of each member can be directed to achieve organizational goals.

A conducive environment will be created by itself if the organizational culture is applied correctly. This will make the work of employees run smoothly, morale will increase, a sense of comfort and security in working is guaranteed, the work environment is kept clean and so on. This situation can affect employees in serving customers well according to company standards, so this can increase customer satisfaction.

\section{The Effects of Leadership Style on Employee Performance}

The results of the research analysis obtained a $\mathrm{t}$-value of $3.072>1.9$, meaning that leadership style has a significant and positive effect on employee performance. The path coefficient with a value of 0.231 means that leadership style contributes to employee performance with a value of $23.1 \%$ and the remaining $76.9 \%$ is another factor that was not examined.

The application of a good leadership style can increase employee morale in complying with regulations and carrying out work according to company goals. If the leadership style is realized properly in accordance with employee expectations, employee performance will also be affected.

\section{Effects of Organizational Culture on Employee Performance}

The results of the research analysis obtained a t-value of $2.487>1.96$, meaning that organizational culture has a significant and positive effect on employee performance. The path coefficient, which is 0.234 , means that organizational culture contributes to 
Janni Tuahman Saragih \& Ahmad Badawi Saluy., Saudi J Bus Manag Stud, Jan, 2022; 7(1): 11-21

employee performance by $23.4 \%$ and the remaining $76.6 \%$ is another factor not investigated.

Implementation of organizational culture by every actor involved in the organization can create a conducive work environment so that employees can work comfortably and safely, high morale arises so that the condition of a good organizational culture can affect employee performance.

\section{Effect of Customer Satisfaction on Employee Performance}

The results of the research analysis obtained a t-value of $4.923>1.96$, meaning that customer satisfaction has a significant and positive effect on employee performance. The path coefficient which is worth 0.466 means that customer satisfaction contributes to employee performance by $46.6 \%$ and the remaining $53.4 \%$ is another factor that was not examined.

Customers who are satisfied with the services provided by employees will continue to use the company's management services and also recommend to their families or other people who live in other housing estates to use environmental management services from the company PT. Sukaputra Graha Cemerlang in Sentul City. Employees who know that customers are satisfied will affect morale to increase so that this can affect employee performance.

The effecs of Leadership Style on Employee Performance through Customer Satisfaction

The results of the research analysis of the indirect effect of leadership style on employee performance obtained a t-value of $2.819>1.96$, meaning that customer satisfaction can mediate the effect of leadership style on employee performance. Customer satisfaction acts as a full mediating where the leadership style can improve employee performance if the customer has high satisfaction

\section{Effects of Organizational Culture on Employee Performance through Customer Satisfaction}

The results of the research analysis of the indirect effect of organizational culture on employee performance obtained a t-value of $4.562>1.96$, meaning that customer satisfaction can mediate the effect between organizational culture and employee performance. Customer satisfaction acts as a full mediating where organizational culture can improve employee performance if customers have high satisfaction.

\section{CONCLUSIONS AND SUGGESTIONS CONCLUSION}

Based on all the findings described above, conclusions can be drawn:
1. Leadership style has a positive and significant effect on customer satisfaction of PT. Sukaputra Graha Cemerlang in Sentul City.

2. Organizational culture has a positive and significant influence on customer satisfaction of PT. Sukaputra Graha Cemerlang in Sentul City.

3. Leadership style has a positive and significant influence on the performance of employees of PT. Sukaputra Graha Cemerlang in Sentul City.

4. Organizational culture has a positive and significant influence on the performance of employees of PT. Sukaputra Graha Cemerlang in Sentul City.

5. Customer satisfaction has a positive and significant impact on the performance of employees of PT. Sukaputra Graha Cemerlang in Sentul City.

6. Leadership style has a positive and significant impact on the performance of PT. Sukaputra Graha Cemerlang in Sentul City mediated by customer satisfaction.

7. Organizational culture has a positive and significant effect on the performance of employees of PT. Sukaputra Graha Cemerlang in Sentul City mediated by customer satisfaction.

\section{SUGGESTIONS}

Based on the conclusions from the research results, several suggestions that can be useful are proposed as follows:

1. Due to the leadership style proven to have a significant and positive effect on customer satisfaction, it is recommended to further improve the implementation and application of leadership styles by paying more attention to the delegation of authority to employees and increasing appreciation for high work performance by employees.

2. Because organizational culture has been proven to have a significant and positive effect on customer satisfaction, it is therefore recommended to further improve organizational culture by giving employees the freedom to innovate and further increasing the level of aggressiveness of employees in carrying out their work.

3. Because customer satisfaction has been proven to have a significant and positive effect on employee performance, it is therefore recommended to increase customer satisfaction by improving environmental management services to customers.

4. Other researchers who will conduct research with similar themes and models are expected to add other factors that can be variables that affect customer satisfaction and employee performance and can expand the object of research not only limited to PT. Sukaputra Graha Cemerlang in Sentul City in order to obtain maximum research results.

\section{BIBLIOGRAPHY}

- Altun, Ö. C., Necati, M., \& Babayigit, M. V. (2017). The Impact of Leadership Styles on Employees Performance in Organization. 
Janni Tuahman Saragih \& Ahmad Badawi Saluy., Saudi J Bus Manag Stud, Jan, 2022; 7(1): 11-21

Conference: The First International Congress On Future Of Tourism: Innovation, Entrepreneurship and Sustainability (Futourism 2017).

- Colquitt, J. A., Jeffery, A. L., \& Michael, J. W. (2019). Organizational Behavior, Sixth Ed. McGraw-Hill, New York.

- Fakhri, M., Pradana, M., Syarifuddin, S., \& Suhendra, Y. (2020). Leadership Style and its Impact on Employee Performance at Indonesian National Electricity Company. The Open Psychology Journal, 13(1), 321-325.

- Genç, K. Y., \& Karadirek, G. (2018). The Impact of Leadership on Customer Satisfaction. Management (16487974), 32(1).

- Ghozali, I. (2014). Structural Equation Modeling: Teori, Konsep dan Aplikasi dengan Program Lisrel 9.10, Edisi 4. Semarang: Badan Penerbit UNDIP.

- Alhakim, R. (2020). Effect of motivation, leadership, and work discipline on employees' performance (Case study of PT. Injakayu Terpadu, Gunung Putri-Bogor). The Management Journal of Binaniaga, 5(1), 23-34.

- Triraharjo, J., Sutawidjaya, A. H., Saluy, A. B., \& Aima, H. (2021). The Influence of Transformational Leadership and Servant Leadership on Employee Satisfaction and Organizational Performance at the Coal Mining Company in Indonesia (IDX-Listed). Linguistica Antverpiensia, 1707-1721.

- Mangkunegara, A. A. A. P. (2017). Manajemen Sumber Daya Manusia. Bandung: PT. Remaja Rosdakarya.

- Muizu, Wa Ode, Z., \& Sari, D. (2019). Improving Employee Performance Through Organizational Culture, Leadership, and Work Motivation: Survey On Banking Organizations In Southeast Sulawesi. Jurnal Bisnis dan Manajemen, 20(1), 71-88.

- Nursiti, D., \& Fedrick, D. (2018). Pengaruh Kinerja Karyawan Terhadap Kepuasan dan Loyalitas Pelanggan Chatime Focal Point Medan. Jurnal Psychomutiara, 2(1), 46-56.

- Saluy, A. B., \& Kemalasari, N. (2018). The Role of Organizational Culture, Organizational Commitment, and Styles of Transformational Leadership towards Employee Performance. In ICBEAS 2018: International Conference on Business, Economic and Administrative SciencesInternational Journal of Industrial and Systems Engineering-Amsterdam, The Netherlands. International Scholarly and Scientific Research \& Innovation, 12(8), 2018.

- Kemalasari, N., \& Saluy, A. B. (2018). The Effect of Human Capital, Structural Capital and Relation Capital on Company Performance. Saudi Journal of Humanities and Social Sciences (SJHSS), 3(5), 642-650.

- Nuryanto, U. W., Mz, M. D., Sutawidjaya, A. H., \& Saluy, A. B. (2020). The Impact of Social Capital and Organizational Culture on Improving
Organizational Performance. International Review of Management and Marketing, 10(3), 93.

- Paschal, A. O., \& Nizam, I. (2016). Effects of organisational culture on employees performance: case of Singapore telecommunication. International Journal of Accounting \& Business Management, 4(1), 19-26.

- Rahmaddian, R., Surapto, D., \& AK, S. M. A. (2021). The Effect of Local Culture, Institutional Organizational Culture on Employee Performance and Customer Satisfaction with Services. Budapest International Research and Critics Institute (BIRCI-Journal): Humanities and Social Sciences, 4(1), 1123-1134.

- Rekarti, E., Doktoralina, C. M., \& Saluy, A. B. (2018). Development model of marketing capabilities and export performance of SMEs: A proposed study. European Journal of Business and Management, ISSN, 2222-1905.

- Rivai, Veithzal dan S., \& Ella, J. (2015). Manajemen Sumber Daya Manusia Untuk Perusahaan, Dari Teori ke Praktek. Jakarta: PT. Raja Grafindo Persada.

- Salahat, M. A., Halim, A., \& Majid, B. M. (2016). Linking leadership styles to customer satisfaction of Palestinian insurance sector: Mediating role of employees' performance. International Journal of Advanced and Applied Sciences, 3(11), 73-82.

- Saluy, A. B., \& Treshia, Y. (2018). Pengaruh motivasi kerja, disiplin kerja dan kompensasi terhadap kinerja karyawan (Studi Kasus di Perusahaan PT IE). Jurnal Ilmiah Manajemen and Bisnis, 2(1), 53-70.

- Saluy, A. B., Musanti, T., \& Mulyana, B. (2019). Pengaruh Pelatihan, Motivasi Kerja dan Kompetensi Terhadap Kinerja Personel Di Makosek Hanudnas I. Journal Of Management And Business Review, jilid, 16, 87-109.

- Saluy, A. B., Prawira, B., \& Buntaran, D. F. A. A. (2019). The Influence of Leadership, Working Culture, and Working Environment for the Ministry of Administrative Reform and Bureaucracy. International Journal of Business and Economic Affairs, 4(5), 224234.

- Siagian, S. P. (2015). Manajemen Sumber Daya Manusia. Jakarta: Bumi Aksara.

- Sinambela, L. P. (2016). Manajemen Sumber Daya Manusia Membangun Tim Kerja yang Solid untuk Meningkatkan Kinerja. Jakarta: Bumi Aksara.

- Siswanto, R. D., \& Hamid, D. (2017). Pengaruh Gaya Kepemimpinan Terhadap Kinerja Karyawan (Studi pada karyawan divisi Human Resources Management Compensation and Benefits PT Freeport Indonesia). Jurnal Administrasi Bisnis, 42(1), 189-198.

- $\quad$ Siwu, P. N., Pio, R. J., \& Liando, D. M. (2014). Pengaruh Kepemimpinan, Budaya Organisasi, Kualitas Pelayanan Terhadap Kepuasan Pelanggan 
Janni Tuahman Saragih \& Ahmad Badawi Saluy., Saudi J Bus Manag Stud, Jan, 2022; 7(1): 11-21

PT. Astra Internasional, Tbk. Daihatsu Cabang Malalayang. Jurnal Ilmiah Society, 22(1), 50.

- Sumarwan, U. (2015). Perilaku Konsumen: Teori dan Penerapannya dalam Pemasaran. Bogor: Ghalia Indonesia.

- Supranto, J. (2013). Pengukuran Tingkat Kepuasan Pelanggan Untuk Menaikkan Pangsa Pasar, cet. III, PT. Rineka Cipta, Jakarta.

- Treshia, Y., \& Saluy, A. B. (2018). Pengaruh motivasi kerja, disiplin kerja dan kompensasi terhadap kinerja karyawan (Studi Kasus di Perusahaan PT IE). Jurnal Ilmiah Manajemen and Bisnis, 2(1), 53-70.

- Yukl, G. (2015). Leadership in Organizations, Seventh Edition, PT. Indeks, Jakarta.

- Yusuf-Habeeb, M., \& Ibrahim, Y. (2017). Effects of Leadership Style on Employee Performance in Nigerian Universities. Global Journal of Management and Business Research: A Administration and Management, 17(7). 